\title{
Néhány fém-organikus vegyület molekuláris mágnességének vizsgálata Mössbauer-spektroszkópiával
}

\author{
KUZMANN Ernö*, HOMONNAY Zoltán, KLENCSÁR Zoltán** és SZALAY Roland \\ ${ }^{a}$ ELTE Kémiai Intézet, 1117, Pázmány P. s. 1/A., Budapest
}

\section{Bevezetés}

A modern molekuláris kémia egyik igen érdekes területe a mágneses molekulák és molekulacsoportok [1-3] előállítása és vizsgálata, amelyek a molekuláris spintronikában, a kvantumtechnológiában, fém-organikus vázakban és $2 \mathrm{D}$ anyagokban [4,5] lehetnek többek között alkalmazhatók. A nagyhatékonyságú információfeldolgozásra alkalmas eszközöknél, például nagy kapacitású tárolóként való alkalmazás esetén, két állapotot megkülönböztetni képes, bistabilis, memóriahatást mutató vegyületek szükségesek, amelyek spinátmenetet mutató anyagokkal és a molekula alapú mágnesekkel lehetnek megvalósíthatók.

A spinátmenet olyan molekulákban játszódik le, amelyek oktaéderes koordinációjú, átmenetifém-iont tartalmaznak, amelyek mind kisspinű (LS) mind nagyspinü (HS) állapotban is elöfordulhatnak. A leggyakrabban vizsgált spinátmenetet mutató molekulák a $\mathrm{Fe}^{\mathrm{II}}$-vegyületek [6,7]. A spinátmenet bekövetkezhet a hőmérséklet, a nyomás változtatásával vagy fény hatására is. $\mathrm{Az} 1$. ábra $\mathrm{Fe}^{\mathrm{II}}$ esetén mutatja a $3 d$ héjon lévő elektronok elhelyezkedését kisspinü és nagyspinü konfiguráció esetén, valamint a hozzájuk tartozó entalpia görbéket. Alacsony hömérsékleten termodinamikai szempontból a kisebb entalpiájú kisspinű LS állapot a stabilabb, de ha a hőmérséklet meghalad egy bizonyos értéket, a nagyspinü HS állapot lesz a termodinamikailag stabilabb állapot. A spinátmenet molekuláris jelenség, ami az intermolekuláris kölcsönhatásoktól is függ. Vegyületek spinátmenete esetén az egész kristályrács részt vesz a folyamatban.

A molekulaalapú mágnesek esetén az egymolekulamágnesek (single molecule magnet, SMM) kiemelkedő jelentőséggel rendelkeznek. Az SMM egymolekulamágnesek olyan fémorganikus vegyületek [8], amelyek egy bizonyos, a molekuláris méretskálának megfelelő hőmérséklet alatt szuperparamágnességet mutatnak. Az SMM-k [8-11] általában szerveskémiai csoportokkal körülvett, egyszerü ligandumokkal (oxid, alkoxid, halid) kapcsolódó paramágneses ionokból alkotott klasztereket tartalmaznak (2a és $2 \mathrm{~b}$ ábra). A klaszteren belül a paramágneses ionok a szuperkicserélődési kölcsönhatások révén ferro- vagy ferrimágnesesen csatolódnak, ami egy óriási eredő spint hoz létre elegendően alacsony hőmérsékleten.

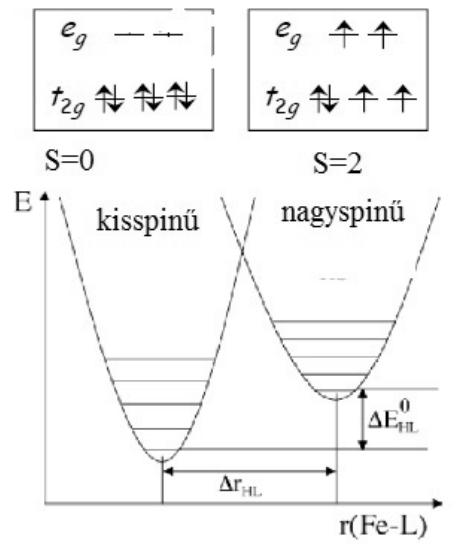

1. Ábra. 3d héjon lévő elektronok elhelyezkedése kisspinü és nagyspinü konfiguráció esetén $\mathrm{Fe}^{\mathrm{II}}$ vegyületben és a hozzájuk tartozó entalpiagörbék a vas-ligandum távolság függvényében
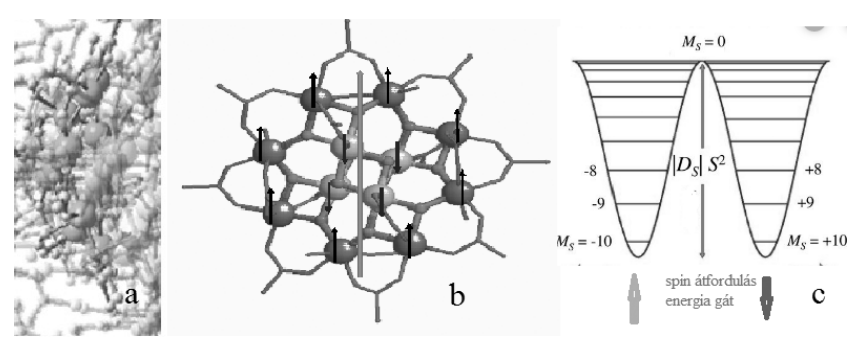

2. Ábra. Szerves héj által körülvett SMM klaszter (a) Mn12-acetát SMM klasztere a spinek feltüntetésével (b) és az SMM eredő spin átfordulás energiaviszonyai (c)

Például, a Mn12-acetát SMM $\left(\left[\mathrm{Mn}_{12} \mathrm{O}_{12}\left(\mathrm{CH}_{3} \mathrm{COO}\right)_{16}(\mathrm{H} 2 \mathrm{O})_{4}\right]\right.$. $2 \mathrm{CH}_{3} \mathrm{COOH} \cdot 4 \mathrm{H}_{2} \mathrm{O}$ ) [9-11] esetén (2b. ábra) 8 darab $\mathrm{S}=2$ spinű $\mathrm{Mn}^{\mathrm{III}}$ ion spinje ellentétesen orientálódik a 4 da$\mathrm{rab} \mathrm{S}=3 / 2$ spinü $\mathrm{Mn}^{\mathrm{IV}}$ ionéhoz képest és egy óriási, $\mathrm{S}=8 * 2-4 * 3 / 2=10$ eredő spint ad $35 \mathrm{~K}$ alatti hőmérsékleten. Külső mágneses tér alkalmazásával ez az eredő spin átfordítható az ellenkező irányba. A SMM-ek jellegzetessége az, hogy az átfordított eredő spin a mágneses tér kikapcsolása után is megmarad, a spin átforduláshoz szükséges energiagát magassága $|\mathrm{D}| S^{2}$ ahol $\mathrm{D}$ az axiális zérus tér felhasadás paramétere [8] (2c ábra). A jelenség a molekulák közötti kölcsönhatás nélkül történik. A szerves ligandumok elszigetelik a molekulákat. Mivel így egy molekula 1 bit tárolására lenne használható, ez lehetővé tenné, hogy az SMM molekulákat rendkívülien nagy adatsürüségü tárolóként alkalmazzák majd a jövőbeli kvantumszámítógépekben [12].

\footnotetext{
* Főszerző. Tel.: 3613722500/1152 fax: 3613722592 ; e-mail: kuzmann@caesar.elte.hu

** Jelen munkahely Energiatudományi Kutatóközpont, 1121 Budapest, Konkoly-Thege M. u 29-33.
} 
Számos SMM komplex tartalmaz vasat, például az úgynevezett $\mathrm{Fe} 4, \mathrm{Fe} 8$ és $\mathrm{DyFe}_{3}$ vegyületek, amelyek vizsgálatára a Mössbauer-spektroszkópia előnyösen alkalmazható [13-17]. Ugyanis napjainkra a Mössbauer-spektroszkópia [18-21] egy széleskörüen alkalmazott nukleáris anyagvizsgálati módszerré vált, amely 13-15 nagyságrend pontossággal képes mérni az elektronok és atommagok között fellépő hiperfinom kölcsönhatásokat, ezáltal a Mössbauerparamétereken (izoméreltolódás, kvadrupólus-felhasadás és mágneses felhasadás) (3. ábra) keresztül információt adni rendre a lokális elektronsürüségről, a lokális elektromos térgradiensről és a lokális effektív mágneses térről.

A vas-komplexekben a spinátmenetek meghatározására a Mössbauer-spektroszkópia diagnosztikai módszerként alkalmazható [19]. Ez azon alapul, hogy mind a $\mathrm{Fe}^{\mathrm{II}}$ mind a Fe ${ }^{\mathrm{III}}$ esetében egymástól jól megkülönböztethetö, eltérő izoméreltolódás és kvadrupólus-felhasadás értékek jellemzök a kisspinü és nagyspinű vegyületekre, továbbá, hogy a kisspinú állapotra kisebb izoméreltolódás, valamint $\mathrm{Fe}^{\mathrm{II}}$ vegyületekre kisebb, $\mathrm{Fe}^{\mathrm{III}}$ vegyületekre nagyobb kvadrupólus-felhasadás jellemző, mint a nagyspinü állapotra [7].

Ezt illusztrálja, hogy például a kisspinủ $\mathrm{Fe}^{\mathrm{II}}$ vegyületekre tipikus izoméreltolódások $\delta=-0.1-0.2 \mathrm{~mm} / \mathrm{s}$, a kvadrupólus-felhasadások $\Delta=0.2-1.0 \mathrm{~mm} / \mathrm{s}$ közé esnek, amíg a nagyspinü $\mathrm{Fe}^{\mathrm{II}}$ vegyületekre tipikus izoméreltolódások $\delta=$ $0.9-1.3 \mathrm{~mm} / \mathrm{s}$, a kvadrupólus-felhasadások $\Delta=2.0-2.7$ $\mathrm{mm} / \mathrm{s}$ tartományban vannak szobahömérsékleten [19, 22], amely Mössbauer-paraméter tartományok nincsenek átfedésben egymással.

Az egymolekula-mágnes fémorganikus vegyületek kutatásában a vasat tartalmazó SMM vegyületek esetén a ${ }^{57} \mathrm{Fe}$ -
Mössbauer-spektroszkópia előnyösen alkalmazható az oxidációs állapot, a spinállapot, a vas-mikrokörnyezet és a vas-ligandum kötések jellemzésére. A Mössbauer-mérések révén feltárható a hiperfinom tér eredete. Követhetők segítségével a vastartalmú SMM vegyületekben végbemenő relaxációs folyamatok. A Mössbauer-spektroszkópia alkalmas a mágneses csatolások jelzésére és megkülönböztetésére. Ugyanis a kicserélödési kölcsönhatáson alapuló kollineáris mágneses csatolások (ferromágneses, antiferromágneses és ferrimágneses) elkülöníthetők külső mágneses tér alkalmazásával [23].

Jelen cikkünkben néhány olyan újabb eredményünket mutatjuk be, amelyeket vas-bisz-glioximokban, oxigénben kezelt vas-ftalocianinokban és lineáris SMM vaskomplexekben a spinátmenetekre illetve a mágneses csatolásra vonatkozóan kaptunk a Mössbauer-spektroszkópia segítségével az ELTE TTK Kémiai Intézetében.

\section{Ligandumcsere hatására bekövetkezö spinátmenet vas-bisz-glioximokban}

Az elmúlt évtizedekben laboratóriumunkban, nemzetközi kollaborációban, számos új típusú vas(II)-azometint (Schiffbázisok, oximok, hidrazonok, szemi- és tioszemikarbazonok, porfirinek, stb.), rákellenes gyógyszeralapanyagként is '́géretes vegyületeket, állítottunk elő és karakterizáltuk, többek között (tömegspektrometria, röntgendiffraktometria, UV-vis, IR, TG, DTG, DTA, biológiai tesztek, DFT számítások) ${ }^{57} \mathrm{Fe}$ Mössbauer-spektroszkópiával is [24-29]. Azt tapasztaltuk, hogy redukálószerek jelenlétében a síknégyzetes $\left[\mathrm{Fe}^{\mathrm{II}}(\mathrm{DioxH})_{2}\right]$ szerkezet könnyen képez jól kristályosodó oktaéderes $\left[\mathrm{Fe}^{\mathrm{II}}(\mathrm{DioxH})_{2} \mathrm{~L}_{2}\right]$ szerkezetet tartalmazó komplexeket.
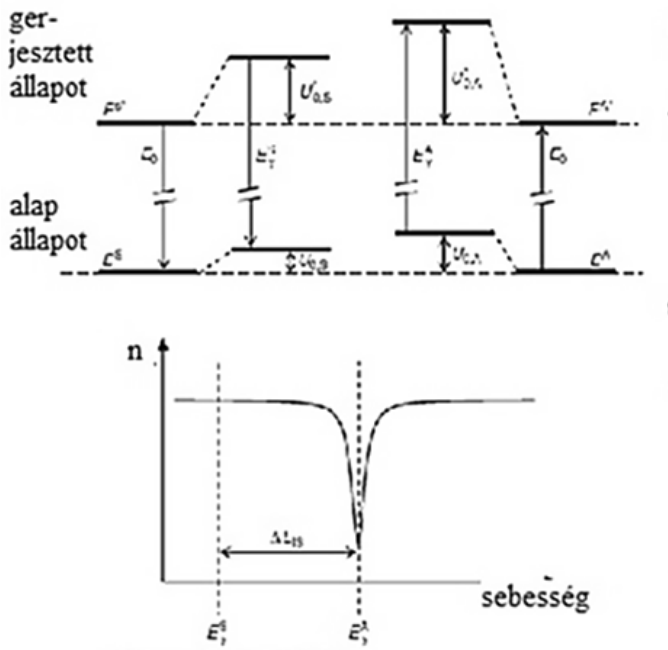

izoméreltolódás

$$
\delta_{\mathrm{c}}=C \Delta \rho_{\mathrm{e}}(0) \frac{\Delta R}{R}
$$
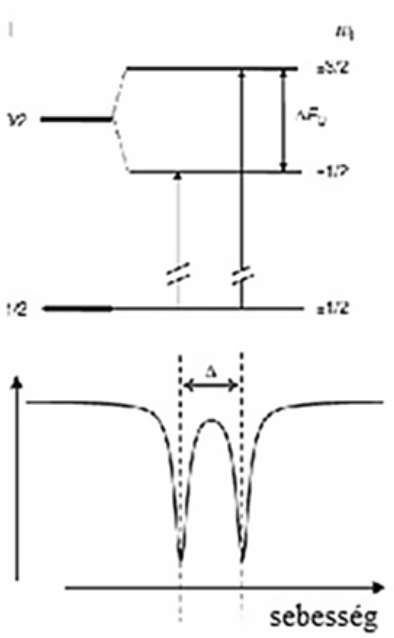

kvadrupólus felhasadás

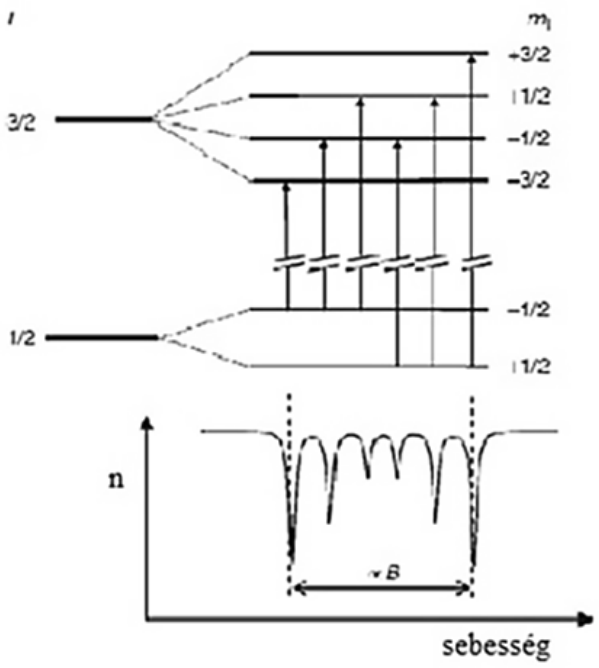

mágneses felhasadás

$$
\Delta E_{\mathrm{m}}=-g_{l} \mu_{\mathrm{N}} B \Delta m_{l}=-g_{l} \mu_{\mathrm{N}} B
$$

3. Ábra. A hiperfinom kölcsönhatásokhoz tartozó energiaszint-diagramok 3/2-1/2 magspinű átmenet esetén és a megfelelö Mössbauer-paraméterek spektrumbeli sematikus ábrázolása 
A 4a ábrán a [vas(metil-etil-glioxim) ${ }_{2}$ (2-imidazolidon) ${ }_{2}$ ] szobahőmérsékleti Mössbauer spektruma látható. A Mössbauer-paraméterek alapján, (izoméreltolódás $\delta=0.12 \pm 0.01$ $\mathrm{mm} / \mathrm{s}$, kvadrupólus-felhasadás $\Delta=0.73 \pm 0.02 \mathrm{~mm} / \mathrm{s}) \mathrm{meg}$ állapítható, hogy a [vas(metil-etil-glioxim) ${ }_{2}$ (2-imidazolidon) $)_{2}$ ] komplex esetében a központi vas atom kisspinü $\mathrm{Fe}^{\mathrm{II}}$ állapotban van [26]. Kutatásunk során számos aromás és heterociklusos axiális ligandummal rendelkező metil-etililletve dimetil glioximot megvizsgáltunk és meghatároztuk az egyes vegyületeket jellemző Mössbauer-paramétereket, amelyek a vasat mindig kisspinü állapotban lévőnek tükrözték [24]. Ilyen módon megállapítottuk, hogy a kis térigényü síkbeli ligandumokkal rendelkező bisz-glioxim alapú komplexekben a vas oxidációs állapota $\mathrm{Fe}^{\mathrm{II}}$ és mindig kisspinü állapotban van. Ez az eredmény jól összeegyeztethető a más módszerekkel kapható eredményekkel valamint az elméleti számításokkal is, amelyek a Fe-N atomtávolságokra $0.2 \mathrm{~nm}$ alatti értékeket adtak [24], ami a kisspinü Fe ${ }^{\mathrm{II}}$ esetén jellemző [7,19] .

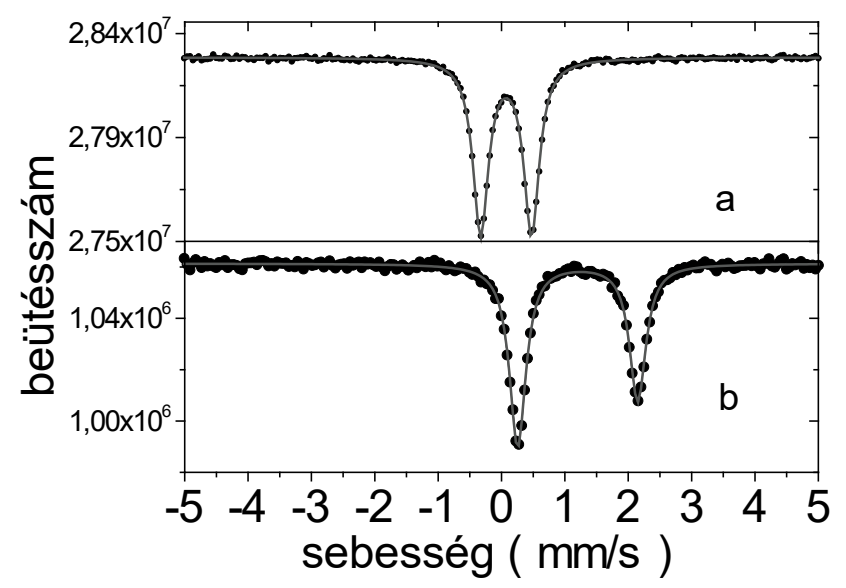

4. Ábra. A [vas(metil-etil-glioxim $\left.)_{2}(2 \text {-imidazolidon })_{2}\right]$ (a) és [vas(metil-izopropil-glioxim $)_{2}$ (2-imidazolidon $)_{2}$ ] (b) szobahőmérsékleten mért Mössbauer-spektrumai. Megjegyezzük, hogy mágikus szögben történt Mössbauer-méréssel bizonyítani lehetett, hogy a 4b ábrán látható kvadrupólus vonalpár területében megfigyelhető különbség oka a textúra [26].

Amennyiben az etil csoportot egy nagyobb térigényü izobutil csoporttal helyettesítettük az oxim síkban (5. ábra), dramatikus változást figyeltünk meg a Mössbauerspektrumban a kis térigényü etilt tartalmazó vegyület (4a ábra) spektrumához képest, amit a $4 \mathrm{~b}$ ábrán bemutatott [vas(metil-etil-izobutil) $)_{2}(2 \text {-imidazolidon) })_{2}$ szobahömérsékleti Mössbauer spektruma jól tükröz. A Mössbauerparaméterek, izoméreltolódás $(\delta=1.24 \pm 0.01 \mathrm{~mm} / \mathrm{s}$, kvadrupólus-felhasadás $\Delta=2.68 \pm 0.02 \mathrm{~mm} / \mathrm{s}$ ) nagyspinü $\mathrm{Fe}^{\mathrm{II}}$ állapotot tükröznek [26]. Eredményünk szerint tehát a vas-bisz-glioxim alapú komplexekben a kis térigényű oldalláncok nagyobb térigényü ligandumokra történő cseréje - a komplexben található vas-atom spinállapotát kisspinűből - nagyspinüre változtatja.

A spinállapotban tapasztalt eltérés figyelemre méltó, mivel a komplexek szerkezete hasonló. A vas atomot mindkét esetben 6-6 nitrogén koordinálja egy bipiramisos szerkezetben, az eltérés a glioximok oldalláncaiban található (Fig. 5).
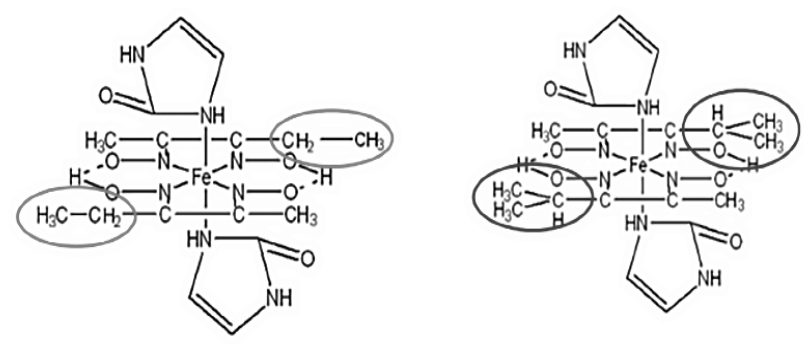

5. Ábra. A [vas(metil-etil-glioxim) $)_{2}(2 \text {-imidazolidon })_{2}$ (bal oldalon) és [vas(metil-izopropil-glioxim) $)_{2}(2 \text {-imidazolidon })_{2}$ ] (jobb oldalon) szerkezeti képlete

Annak az oka, hogy a nagyobb térigényü elágazó láncú ligandumot tartalmazó glioxim komplexben a nagyspinü állapot kedvezőbb az, hogy a nagyobb térigényü ligandumok hatására a molekulageometria megváltozik, mégpedig olyan módon, hogy ezzel a planáris helyzetű nitrogén atomok és a vas atom közti kötéstávolságok megnövekednek. Ez a növekedés olyan mértékü, hogy a Fe-N kötéstávolság átlépi a kritikus távolságot, aminek következtében a nagyspinü állapot lesz kedvezőbb [7].

Eredményünket a más módszerekkel kapott eredmények is alátámasztják, továbbá az elméleti számítások is, amelyek az izopropil helyettesített glioxim komplexekben $0.23 \mathrm{~nm}$ Fe-N kötéstávolságot becsültek, amely esetén a nagyspinü állapot a stabilis.

\section{Hőmérsékletfüggő spinátmenet és antiferromágneses kölcsönhatás oxigénben kezelt vas-ftalocianinokban}

Korábbi munkánkban, a tudományos és technológiai érdeklődés homlokterében álló nanofázisú anyagok kutatásával kapcsolatosan, új eljárást sikerült találnunk ferromágneses vaskarbidok karbon nanocsövekbe történő befoglalására vas-ftalocianin pirolízisével [30], ami megnöveli ezek alkalmazhatóságát [31] (pl. mágneses adattárolókban, nyomtató festékekben, ferrofluidokban), a Philadelphiai Drexel Egyetemmel történő együttműködés keretében. A karbon nanokapszulázott vaskarbidok képződésével kapcsolatos mechanizmus megértése végett a béta módosulatú vas ftalocianint oxigénben kezeltunk viszonylag alacsony hőmérsékleteken száraz és nedves körülmények között és az oxigén beépülését, valamint a rácsban való elhelyezkedését vizsgáltuk Mössbauer-spektroszkópia, röntgendiffraktometria, elektronmikroszkópia és IR spektroszkópia segítségével [32-36].

A 6. ábrán bemutatott szobahőmérsékleti Mössbauerspektrumok jól mutatják, hogy az oxigénmentes $\beta$-ftalocianin (6a ábra) egyetlen viszonylag nagy kvadrupólus- felhasadással $(\Delta=2.54 \pm 0.02 \mathrm{~mm} / \mathrm{s})$ rendelkező dublettet mutató spektrumához képest lényegesen kisebb kvadrupólus felhasadással rendelkező új spektrumkomponensek lépnek fel az oxigénben kezelt ftalocianinok spektrumában (6b-d ábra), amelyek az oxigén adduktokhoz társíthatók. Megfigyelhetö, hogy a komponensek száma és előfordulása függ az oxi- 
génbevitel körülményétől és nő a beépülő oxigén mennyiségével. Sikerült olyan körülményeket találnunk, amelyek mellett az oxigén beépül és azt tapasztaltuk, hogy az oxigén jelentős mértékben diffundál be a szilárd állapotú vas-ftalocianin rétegei közé és ott nagy mennyiségben stabilizálódik, ami az oldat állapotú vas-ftalocianinban nem fordul elő. Az oxigén elhelyezkedésére vonatkozóan 4 különböző mikrokörnyezetet találtunk a $\beta$ módosulatú vas ftalocianinban [32]. Az oxigénbevitel hatására kialakuló komponensek között $\mu$-oxo-hidas és peroxo specieszeket is azonosítottunk.

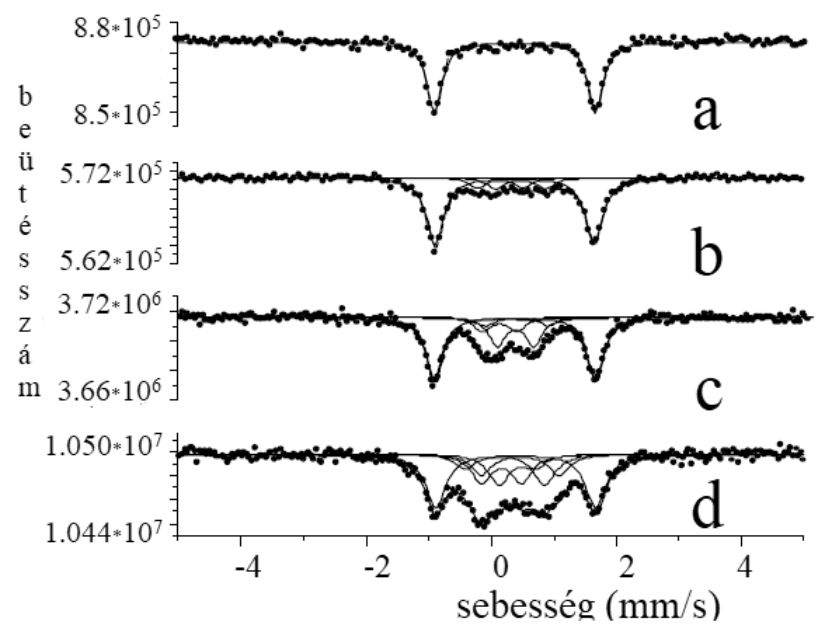

6. Ábra. Eredeti oxigénmentes (a) és oxigénben kezelt $\beta$-vas-ftalocianinok szobahőmérsékleti Mössbauer-spektrumai, szobahőmérsékleten $\mathrm{O}_{2} / \mathrm{H}_{2} \mathrm{O}$ áramban 14 napig (b) $50{ }^{\circ} \mathrm{C}$ hőmérsékleten $\mathrm{O}_{2} / \mathrm{H}_{2} \mathrm{O}$ áramban 14 napig (c) és $50{ }^{\circ} \mathrm{C}$ hömérsékleten $\mathrm{O}_{2}$ áramban 92 napig (d)

A $\beta$-módosulatú vas-ftalocianinra vonatkozó további vizsgálatainkban hőmérsékletfüggő spinátmenetet találtunk az egyik Fe ${ }^{\mathrm{III}}$ komponensre vonatkozóan [32, 34]. Ezt illusztrálják a 7 . ábrán bemutatott, körülbelül $60 \%$ oxigén adduktot eredményezö, oxigénben kezelt $\beta-F e P c$ Mösbauerspektrumok, ahol a kisspinü c komponens relatív területe nö, amíg a nagyspinü d komponens területe csökken a hömérséklet 77 K-röl 292 K-re való növekedése során.

Tovább folytatva kutatásainkat sikerült olyan elöállítási paramétereket találnunk, amelyeknél 93\% oxigéntelítettség volt elérhető, ahol a $\beta$-vas-ftalocianin oxigénben való kezelése során a rétegek közé beépülő oxigén specieszek közül csak az lép fel, ami egy hőmérsékletfüggő spinátmenetet mutat [35]. Ezt szemléltetik a Mössbauer-spektrumok a 8. ábrán, ahol jól látható a b komponens fokozatos növekedése a c komponens rovására a hömérséklet növekedtével.

A Mössbauer-mérések egyértelműen jelezték, hogy az $\beta$-vas ftalocianin oxigénben való kezelése során új specieszek

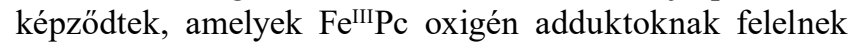
meg kisspinü és nagyspinü állapotban. A hőmérsékletfüggő Mössbauer-mérések azt mutatták, hogy a hőmérséklet növelés hatására a kisspinű speciesz a nagyspinű specieszbe alakul át [35].

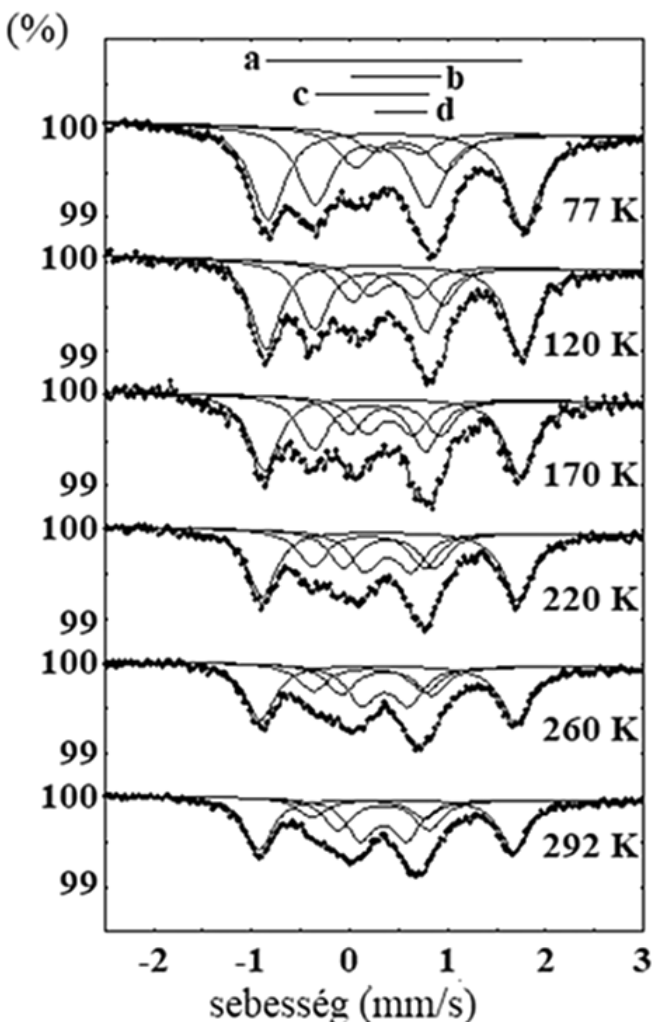

7. Ábra. $\mathrm{Az} 50{ }^{\circ} \mathrm{C}$ hőmérsékleten $\mathrm{O}_{2} / \mathrm{H}_{2} \mathrm{O}$ áramban több mint 6 hétig oxigénben kezelt $\beta$-vas-ftalocianinok Mössbauer-spektrumainak hőmérsékletfüggése. A hőmérséklet növekedésével átmenet figyelhető meg a kisspinű $\mathbf{c}$ komponens és a nagyspinű $\mathbf{d}$ komponens között

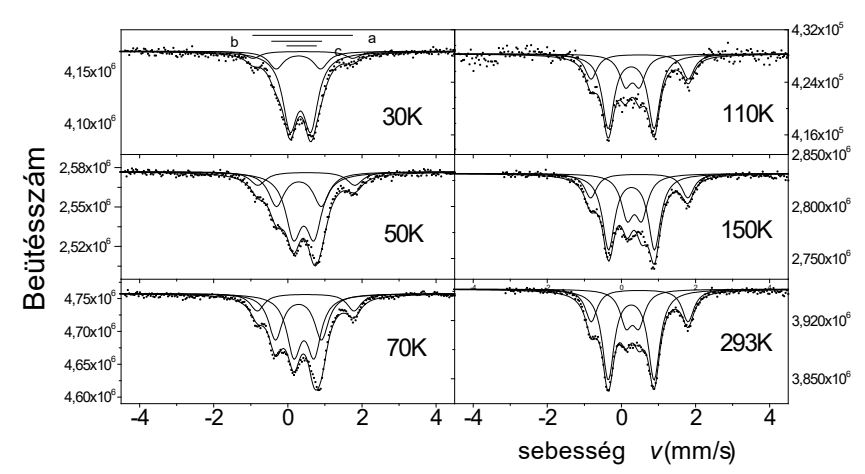

8. Ábra. Az $50{ }^{\circ} \mathrm{C}$ hőmérsékleten $\mathrm{O}_{2} / \mathrm{H}_{2} \mathrm{O}$ áramban 75 napig oxigénben kezelt $\beta$-vas-ftalocianinok Mössbauer-spektrumainak hőmérsékletfüggése. A hőmérséklet növekedésével átmenet figyelhető meg a kisspinű b komponens és a nagyspinü c komponens között

A $\beta$-vas-ftalocianonokon szerzett tapasztalataink birtokában megkíséreltük a hasonló feltételek melletti oxigénben való kezelést az $\alpha$-vas-ftalocianin módosulaton is, amelyen korábban nem sikerült számottevő mennyiségű oxigént stabilizálni a rétegek között. Az oxigénmentes ( $9 \mathrm{a}$ ábra) és kétféle eljárással oxigénben kezelt ( $9 \mathrm{~b}$ és $9 \mathrm{c}$ ábra) alfa módosulatú vas ftalocianin $80 \mathrm{~K}-n$ mért Mössbauer-spektrumainak összehasonlításból jól látható, hogy az oxigénben kezelt minták spektrumaiban az oxigénmentes eredeti minta D1 dublettje, azaz az oxigénnel nem kapcsolódó vasatomok spektrumjáruléka az oxigénben kezelt minták spektrumai- 


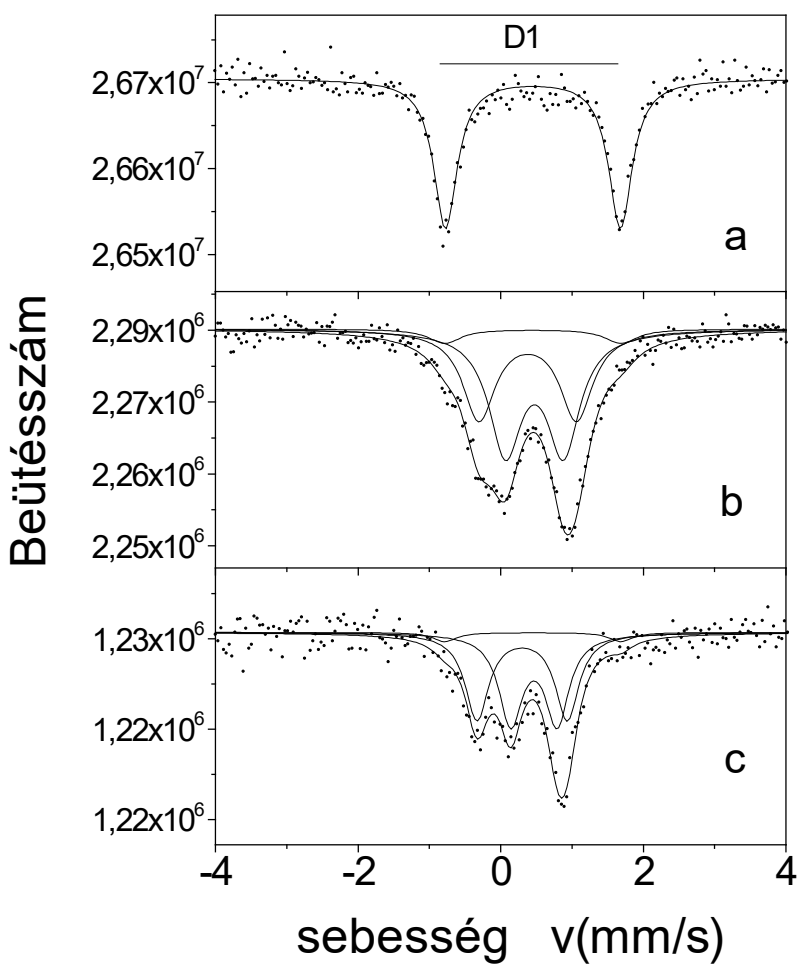

9. Ábra. Eredeti oxigénmentes (a) és oxigénben kezelt $\alpha$-vas-ftalocianinok $80 \mathrm{~K}$-n mért Mössbauer-spektrumai, $50^{\circ} \mathrm{C}$ hömérsékleten $\mathrm{O}_{2}$ áramban 75 napig kezelve (b) és $50^{\circ} \mathrm{C}$ hỏmérsékleten $\mathrm{O}_{2} / \mathrm{H}_{2} \mathrm{O}$ áramban 75 napig kezelve(c)

ban jelentősen lecsökkent (ezzel összhangban a megfelelő komponens szobahőmérsékleten nem is volt kimutatható).

Ílymódon első ízben sikerült az $\alpha$-vas-ftalocianin oxigénben való kezelése, azaz sikerült olyan előállítási paramétereket találnunk, ahol az $\alpha$-vas-ftalocianin oxigénben való kezelése során a rétegek közé oxigéneket úgy lehet beépíteni, hogy valamennyi vasatomnak van oxigén szomszédja.

Még érdekesebb, hogy nem várt módon azt tapasztaltuk, hogy az így elöállt oxigénben kezelt $\alpha$-vas-ftalocianin vegyület ${ }^{57} \mathrm{Fe}$ Mössbauer-spektrumában az egyik összetevő 20 K-n (10. ábra) mágneses felhasadást mutatott $[35,36]$.

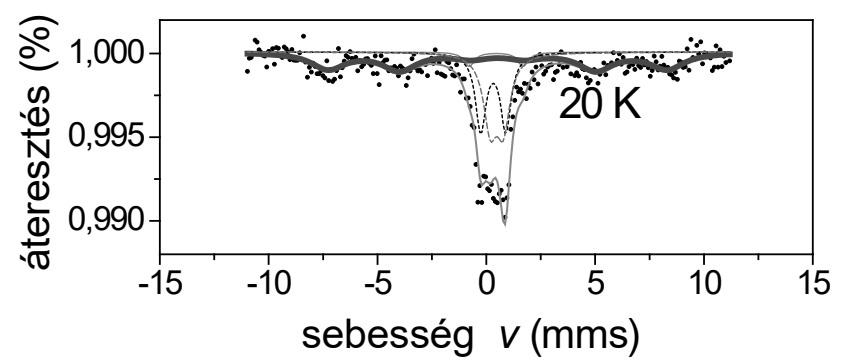

10. Ábra. $50{ }^{\circ} \mathrm{C}$ hőmérsékleten $\mathrm{O}_{2} / \mathrm{H}_{2} \mathrm{O}$ áramban 75 napig oxigénben kezelt $\alpha$-vas-ftalocianin $80 \mathrm{~K}$ hőmérsékleten mért Mössbauer-spektruma
Mivel a paramágneses hiperfinom struktúra megjelenése a vas-ftalocianinban nem várható, felmerült annak a lehetősége, hogy a $20 \mathrm{~K}-n$ tapasztalt mágneses felhasadás egy vas ionok között fellépő mágneses (kicserélődési) kölcsönhatásra és az annak következtében kialakuló mágneses rendeződésre utal. Ennek vizsgálatára ismét a Mössbauerspektroszkópiát alkalmaztuk. Ugyanis, határozottan leegyszerűsítve, külső mágneses tér alkalmazása ugyanis ferromágneses rendszerekben az ${ }^{57} \mathrm{Fe}$ Mössbauer-spektrumban detektált belső mágneses tér nagyságának megváltozásához vezet, míg porszerü antiferromágneses anyagok Mössbauerspektrumaiban változatlan nagyságú átlagos belső mágneses tér érték mellett elsősorban vonalkiszélesedést okoz, ami Mössbauer-spektroszkópiai mérésekkel jól követhető.

A külső mágneses tér nélkül és $5 \mathrm{~T}$ külső mágneses térben lévő, nagymértékben oxigénben kezelt alfa-vas-ftalocianin $5 \mathrm{~K}$ hömérsékleten mért Mössbauerspektrumai a 11. ábrán láthatók. A kiértékelt spektrumok összehasonlítása alapján, legszembetűnőbben abból, hogy a belső mágneses nagysága változatlan maradt a külső mágneses tér alkalmazásának a hatására, megállapítottuk, hogy a vegyületben aniferromágneses kölcsönhatás lép fel [36]. Az antiferromágnességet a párhuzamosan végzett mágnesezettség mérések is igazolták [36].

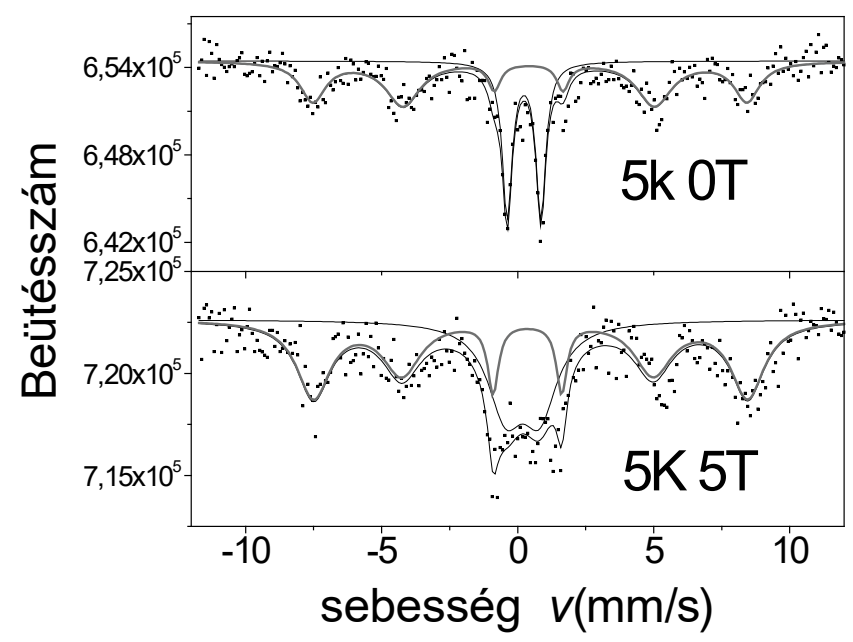

11. Ábra. $50{ }^{\circ} \mathrm{C}$ hőmérsékleten $\mathrm{O}_{2} / \mathrm{H}_{2} \mathrm{O}$ áramban 75 napig oxigénben kezelt $\alpha$-vas-ftalocianin $5 \mathrm{~K}$ hőmérsékleten mért Mössbauer-spektruma külső mágneses tér nélkül (felül) és $5 \mathrm{~T}$, a gamma-sugárzással párhuzamosan alkalmazott külső mágneses térben (alul)

A nagymértékben oxigénben kezelt alfa-vas-ftalocianinokban alacsony hőmérsékleteken megfigyelt antiferromágneses csatolással fellépő mágnességet, a hosszú $\mu$-peroxo -Fe-O-O-Fe- láncok (12. ábra) közötti szuperkicserélődéssel közvetített kicserélődési kölcsönhatással magyaráztuk [36]. 


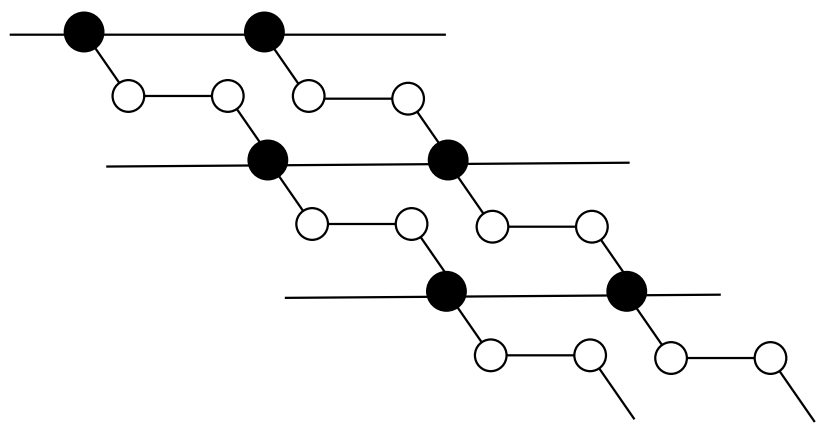

12. Ábra. Az oxigénhidak elhelyezkedésének modellje oxigénben kezelt $\alpha$-vas-ftalocianinban (Fe: telt fekete kör, O: üres kis kör)

\section{Rendkívül nagy hiperfinom tér és ferromágneses kölcsönhatás lineáris, két atom koordinált egymolekula mágnes vas-komplexekben}

A jelen tudományos és technológiai érdeklődés középpontjában álló molekuláris mágnesség többnyire szokatlan geometriával, anizotrópiával rendelkezö molekuláknál valósul meg [1-3, 37], többek között például lineáris geometriájú, két atom által koordinált vaskomplexekben, amelyek sajátos elektromos és mágneses tulajdonságokkal rendelkeznek [38-48].

Egy ilyen molekula a $\mathrm{Fe}\left[\mathrm{C}\left(\mathrm{SiMe}_{3}\right)_{3}\right]_{2}$ is [46], amelynek szerkezete a 13. ábrán látható. Ebben a szerkezetben a vasatomnak csak két első szomszédja van, két szénatom, amelyekkel a vas egy lineáris vegyületet formál. Mindkét szénatomhoz 3-3 szilícium kapcsolódik és minden $\mathrm{Si}$ atomhoz pedig 3 metil kötődik. Ebben a molekulában egy szokatlanul nagy ${ }^{57} \mathrm{Fe}$ hiperfinom mágneses tér volt kimutatható alacsony hömérsékleteken [38-40].

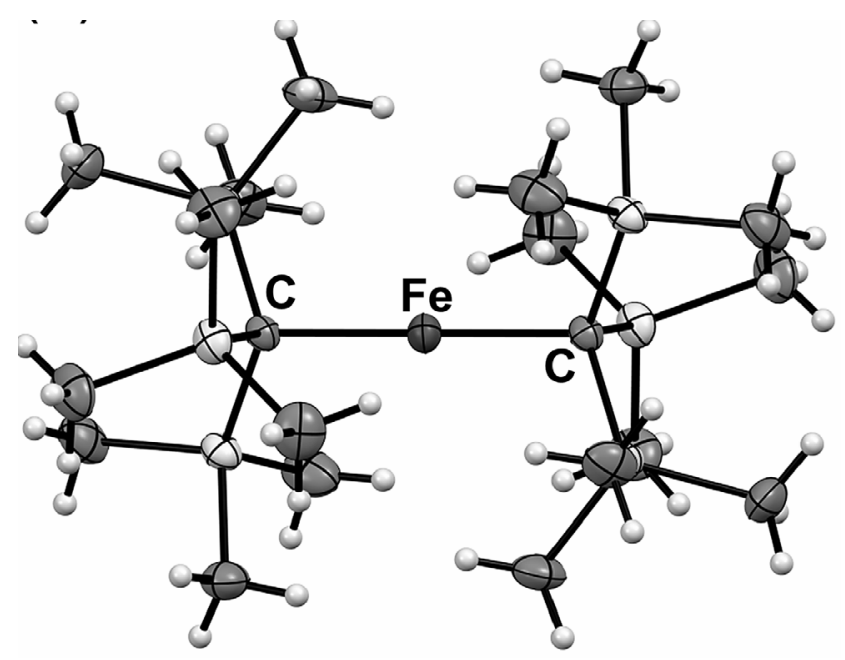

Ezt a $\mathrm{Fe}\left[\mathrm{C}\left(\mathrm{SiMe}_{3}\right)_{3}\right]_{2}$ vegyületet mi is elöállítottuk, majd más módszerek mellett (a vas helyén lévő hiperfinom mágneses tér pontos meghatározására kiválóan alkalmas) ${ }^{57} \mathrm{Fe}-$ Mössbauer-spektroszkópiával is karakterizáltuk annak érdekében, hogy magyarázatot találjunk a vas helyén mutatkozó rendkívül nagy mágneses tér fellépésére [39,40,47,48].

A 14. ábrán a $\mathrm{Fe}\left[\mathrm{C}\left(\mathrm{SiMe}_{3}\right)_{3}\right]_{2}$ vegyület $20 \mathrm{~K}$ hömérsékleten mért ${ }^{57} \mathrm{Fe}$-Mössbaur-spektruma látható. Ebben az analízis alapján egy különlegesen nagy, 157.5 T belső mágneses teret tükröző komponenst figyelhetünk meg [39, 40]. (Tudomásunk szerint ilyen nagy belső mágneses teret eddig még vasvegyületben nem mértek.)

A Fe $\left[\mathrm{C}\left(\mathrm{SiMe}_{3}\right)_{3}\right]_{2}$ vegyületben megfigyelt nagy belső mágneses tér azért meglepő, mert a szokásos vasvegyületek esetén tapasztalt belső mágneses terek általában $55 \mathrm{~T}$ alatt maradnak, ami elsődlegesen a Fermi-kontakt tér járulékának tulajdonítható [21]. Ismeretes ugyanis [23], hogy a vas atommagja helyén mérhető hiperfinom mágneses tér eredetének 3 fö oka van: a Fermi kontakt tér járuléka, $\boldsymbol{B}_{\mathrm{c}}$, a dipól tér járuléka, $\boldsymbol{B}_{\mathrm{d}}$ és a pálya tér járulék, $\boldsymbol{B}_{\mathrm{L}}$. A dipól tér járuléka a Fermi kontakt térhez képest általában kicsi és sokszor ellentétes irányú. A vas esetén, számos átmeneti fémhez hasonlóan a kristályrácsban lévő vas 3d héján a kristálytérrel való kölcsönhatás következtében a pályamomentum befagyott állapotban van, azaz csak olyan atomi pályák alakulhatnak ki, amire nézve az effektív pályamomentum értéke zérus. Ebből kifolyólag a befagyott pálya nem ad járulékot a hiperfinom térhez. A vasvegyületekben időnként előforduló kismértékű pályajárulék a spin-pálya kölcsönhatással hozható kapcsolatba.

A DFT számítással megjósolt egyensúlyi geometria kitűnően egyezett a röntgendiffrakcióval meghatározott geometriával. Továbbá azt találtuk, hogy tisztán a vas nagyspinü állapota a kedvező energetikailag. A DFT analízis azt mutatta, hogy a kötéseknél a vasról a $\mathrm{C}\left(\mathrm{SiMe}_{3}\right)_{3}$ ligandumokra irányuló jelentős mértékű töltéstranszfer lép fel. A számításoknak megfelelően a vizsgált vegyületben az Fe atom elektronkonfigurációja $3 d^{5.83} 4 s^{0.72}$, ahol a 4 s elektronsürüség csak kismértékben polarizált, és a párosítatlan elektronok döntő többsége 3d jellegü [39,40]. A Mössbauermérésekkel talált extrém nagy mágneses tér értéket a szokatlan geometriában (hiányzó Jahn-Teller effektus miatt) nem befagyott $3 \mathrm{~d}$ pálya járulékok hatásának következményeként magyaráztuk meg [40]. Megbecsültük a hiperfinom tér egyes összetevőinek nagyságát is, ami $\boldsymbol{B}_{\mathrm{c}} \approx 44 \mathrm{~T}, \boldsymbol{B}_{\mathrm{d}} \approx$ 14 T és $\boldsymbol{B}_{\mathrm{L}} \approx 99 \mathrm{~T}$, ahol a $\boldsymbol{B}_{\mathrm{L}}$ pálya tér járulék dominál [40].

13. Ábra. $\mathrm{A} \mathrm{Fe}\left[\mathrm{C}\left(\mathrm{SiMe}_{3}\right)_{3}\right]_{2}$ vegyület szerkezete 


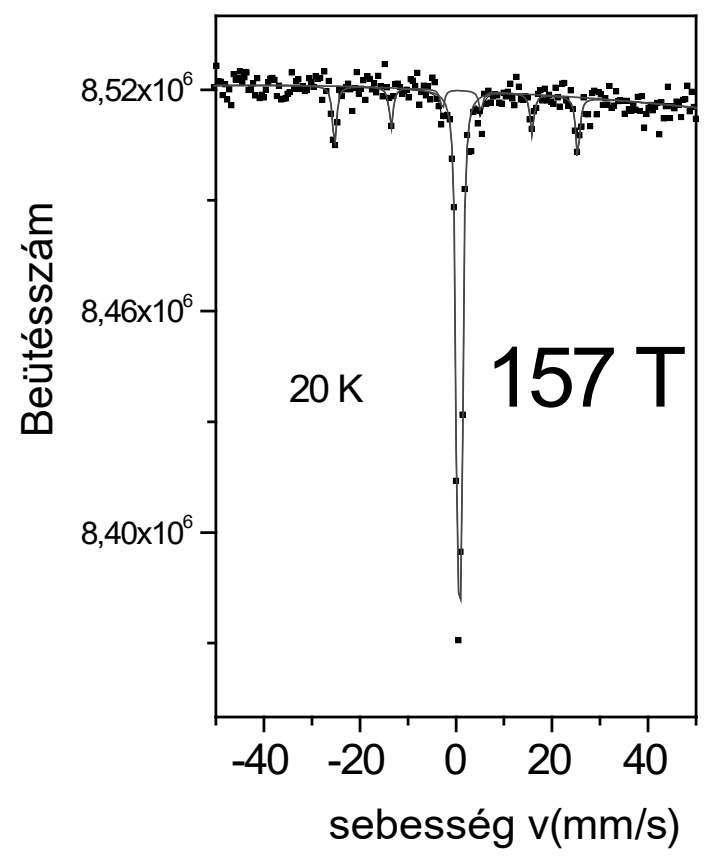

14. Ábra. A Fe $\left[\mathrm{C}\left(\mathrm{SiMe}_{3}\right)_{3}\right]_{2}$ vegyület $20 \mathrm{~K}$-en mért Mössbauer-spektruma

A $\mathrm{Fe}\left[\mathrm{C}\left(\mathrm{SiMe}_{3}\right)_{3}\right]_{2}$ vegyület egymolekula-mágnesként is funkcionál $\mathrm{U}=|D| S^{2}=181 \mathrm{~cm}-1$ energiagáttal az AC szuszceptibilitás mérések alapján [44]. Míg a több vasatomot tartalmazó SMM molekulák klasztereiben a kicserélődési kölcsönhatás a klaszteren belül alapvető jelentőségü [8], nem volt tisztázott, hogy felléphet-e kicserélődési kölcsönhatáson alapuló mágnesség a $\mathrm{Fe}\left[\mathrm{C}\left(\mathrm{SiMe}_{3}\right)_{3}\right]_{2}$ egymolekula-mágnesben, amelyen belül csak egyetlen vasatom van. Ennek tanulmányozására ismét külső mágneses térben történő Mössbauer-méréseket alkalmaztuk, kihasználva azt, hogy a külső mágneses térben végzett Mössbauer-mérések segítségével a mágneses csatolások megkülönböztethetők.

A 15. ábrán $\mathrm{Fe}\left[\mathrm{C}\left(\mathrm{SiMe}_{3}\right)_{3}\right]_{2}$ vegyület ${ }^{57} \mathrm{Fe}$ Mössbauerspektrumai láthatók 5 K-n mérve külső mágneses tér nélkül és $5 \mathrm{~T}$ külső térben. A spektrumok két szextettből állnak.
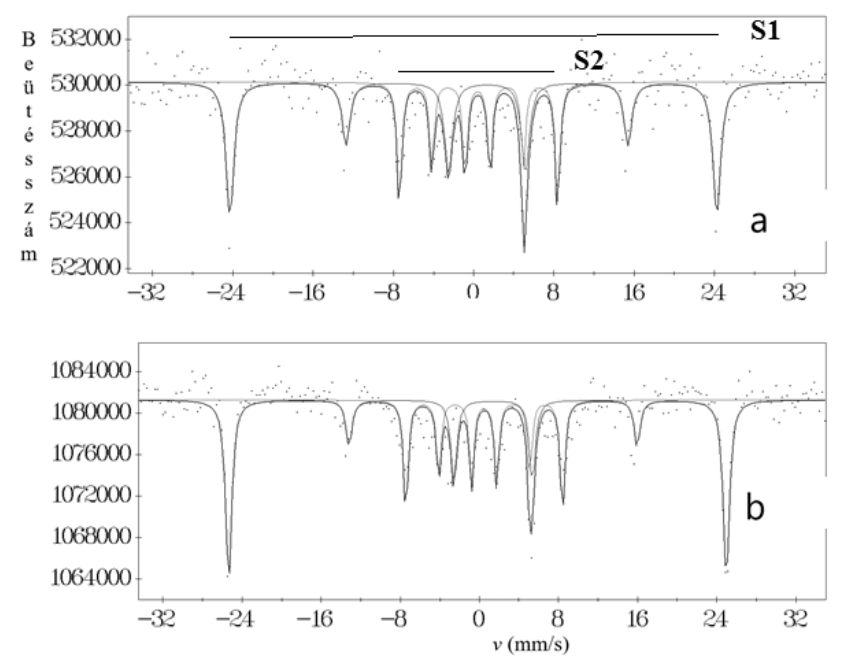

15. Ábra. $\mathrm{A} \mathrm{Fe}\left[\mathrm{C}\left(\mathrm{SiMe}_{3}\right)_{3}\right]_{2}$ vegyület $5 \mathrm{~K}$ hömérsékleten mért Mössbauer-spektrumai külső mágneses tér nélkül (a) és $\boldsymbol{B}_{\text {ext }}$ a gamma-sugárzással párhuzamosan alkalmazott $5 \mathrm{~T}$ külső mágneses térben (b).
S1 szextett, amely szokatlanul nagy mágneses térrel rendelkezik, a $\mathrm{Fe}\left[\mathrm{C}\left(\mathrm{SiMe}_{3}\right)_{3}\right]_{2}$ vegyületben a két szénatom által linárisan koordinált vasatom ujjlenyomata, míg S2 sextett a mintában másodfázisként jelenlévő ferrihidrithez tartozik. Azt tapasztaltuk, hogy a külső mágneses tér hatására S1 szextett által tükrözött belső mágneses tér az alkalmazott külső tér értékével megnövekedett, amíg az antiferromágneses ferrihidrit spektruma változatlan maradt. Ennek alapján megállapítottuk, hogy $\mathrm{Fe}\left[\mathrm{C}\left(\mathrm{SiMe}_{3}\right)_{3}\right]_{2}$ vegyületben ferromágneses kölcsönhatás lép fel [47]. A ferromágneses csatolást igazolta a mágnesezési mérésekben fellépő hiszterézis és nem zérus remanencia is [47].

Értékes, új információ volt várható a vashoz legközelebbi szomszéd atomok vagy ligandumok kicserélése révén, így további kísérleteket végeztünk olyan rokon vegyületeken, melyekben a vassal szomszédos szénatomokat nitrogénre cseréltük. Egy ilyen vegyület $\mathrm{Fe}\left[\mathrm{N}\left(\mathrm{SiPh}_{2} \mathrm{Me}\right)_{2}\right]_{2}$ szerkezetét mutatja a 16. ábra.

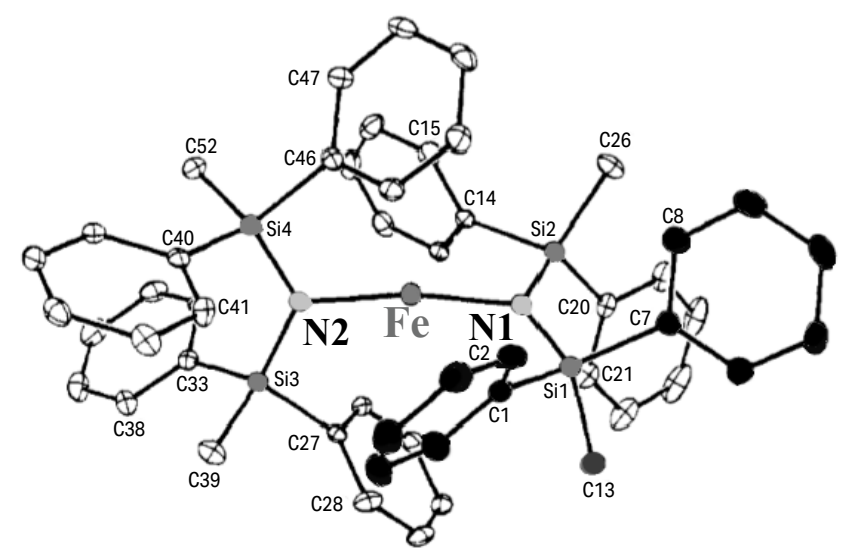

16. Ábra. A Fe $\left[\mathrm{N}\left(\mathrm{SiPh}_{2} \mathrm{Me}\right)_{2}\right]_{2}$ vegyület szerkezete.

A 17. ábrán lévő mágnesesen felhasadt Mössbauerspektrumokban talált szokatlanul nagy belső mágneses tér [48] bizonyítékot szolgáltat a nem befagyott vas pályamomentumra a $\mathrm{Fe}\left[\mathrm{N}\left(\mathrm{SiPh}_{2} \mathrm{Me}\right)_{2}\right]_{2}$ molekulában. A $90 \mathrm{~T}$-nál

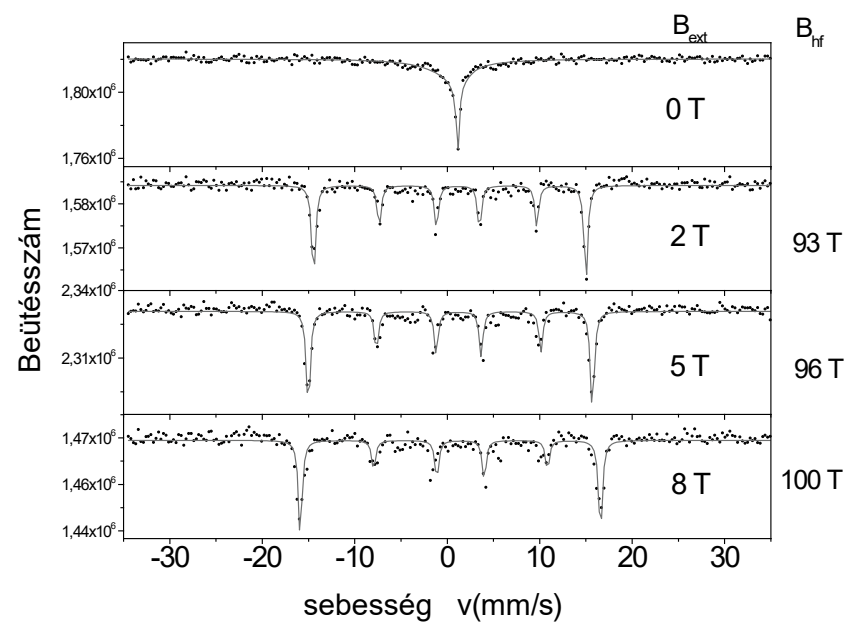

17. Ábra. A Fe $\left[\mathrm{N}\left(\mathrm{SiPh}_{2} \mathrm{Me}\right)_{2}\right]_{2}$ vegyület $5 \mathrm{~K}$ hőmérsékleten mért Mössbauer-spektrumai külső mágneses tér nélkül és $\boldsymbol{B}_{\text {ext }}$ a gamma-sugárzással párhuzamosan alkalmazott külső mágneses térben, a megfigyelt $\boldsymbol{B}_{\mathrm{hf}}$ hiperfinom tér feltüntetésével. 
nagyobb hiperfinom mágneses térérték, ami erre a vegyületre jellemző, sokkal nagyobb annál, mint amit a $\boldsymbol{B}_{\mathrm{c}}$ Fermi kontakt tér és a $\boldsymbol{B}_{\mathrm{d}}$ dipól tér hozzájárulása indokolna a hiperfinom térhez nagy-spinü $\mathrm{Fe}^{\mathrm{II}}$ esetén, következésképpen a szokatlanul nagy nem-befagyott pályamomentum fellépése, azaz az ennek megfelelő $\boldsymbol{B}_{\mathrm{L}}$ pályajárulék okozza a tapasztalt nagy hiperfinom teret.

A 18. ábra korrelációt mutat a hiperfinom tér és a N-Fe-N kötésszög között $\mathrm{Fe}\left[\mathrm{N}\left(\mathrm{SiPh}_{2} \mathrm{Me}\right)_{2}\right]_{2}$ molekulában és rokon vegyületeiben. A hiperfinom tér értéke monoton nő a N-Fe-N szög növekedtével, amely összefüggésbe a Fe[ $\left[\mathrm{N}\left(\mathrm{SiPh}_{2} \mathrm{Me}\right)_{2}\right]_{2}$ esetében talált tér is jól illeszkedik [48]. Ez jól magyarázható azzal, hogy a nem befagyott pályamomentum értéke csökken a N-Fe-N kötés behajlásával, mivel a vas ekkor a nitrogéntől különböző, más atomok hatását is érzi.

$\mathrm{Fe}\left[\mathrm{N}\left(\mathrm{SiPh}_{2} \mathrm{Me}\right)_{2}\right]_{2}$ az alacsony koordinációjú vas komplexek egy további példája, ahol a kvázi szabad-ion mágnesség egy nem-befagyott pálya momentumon keresztül jelenik meg.
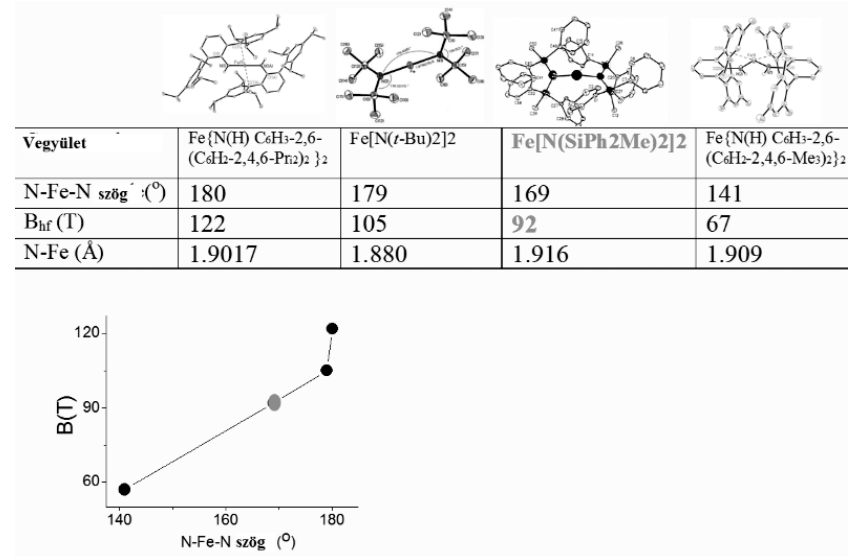

18. Ábra. Korreláció a hiperfinom tér és a N-Fe-N kötésszög között kvázilineáris vas(II)-amido vegyületekben.

A 17. ábrán bemutatott $\mathrm{Fe}\left[\mathrm{N}\left(\mathrm{SiPh}_{2} \mathrm{Me}\right)_{2}\right]_{2}$ vegyület $5 \mathrm{~K}$ hőmérsékleten mért Mössbauer-spektrumainak külső mágneses tértől való függése a $\mathrm{Fe}\left[\mathrm{N}\left(\mathrm{SiPh}_{2} \mathrm{Me}\right)_{2}\right]_{2}$ vegyületben ferromágneses kicserélődési kölcsönhatást jelez [48] hasonlóan a fentebb bemutatott $\mathrm{Fe}\left[\mathrm{C}\left(\mathrm{SiMe}_{3}\right)_{3}\right]_{2}$ esetéhez. A mágnesezettségi görbék alátámasztják a kicserélődési kölcsönhatáson alapuló mágnességet és a Mössbauerspektroszkópiával talált eredményeket [48].

Tapasztalataink arra utalnak, hogy nanoméretű mágneses egységek, mágneses nanoklaszterek képződése történik ezekben a lineáris és kvázi-lineáris kristályos két atom koordinált vas(II)-metil és vas(II)-amido komplexekben, ahol mágneses kölcsönhatás valósulhat meg ezek között a nanoméretű mágneses egységek között. Számos faktor befolyásolhatja a mágneses csatolást, így a ligandumtér erőssége, a spin-pálya csatolás, a nem befagyott pályajárulék, a ligandum összetétel, a ligandumok elrendeződése a rácsban, a molekula-geometria, stb., amelyek részletesebb megismerése további vizsgálatokat igényel.

\section{5. Összefoglalás}

${ }^{57} \mathrm{Fe}$ Mössbauer-spektroszkópia segítségével kimutattuk, hogy a vas-bisz-glioxim alapú komplexekben a kis térigényü alkil oldalláncok nagyobb térigényü elágazó láncú ligandumokra történő cseréje, a komplexben található Fe spinállapotát kisspinűből nagyspinűre változtatja. A ligandumcsere hatására a molekula geometriája megváltozik, aminek következtében a vas-nitrogén kötéstávolságok megnövekednek, így a nagyspinü állapot válik kedvezőbbé.

Oxigénben kezelt $\beta$-Fe-ftalocianin oxigén adduktjaihoz tartozó Mössbauer-paraméterek hőmérsékletfüggése alapján a kisspinü és nagyspinű oxigén adduktok közötti hőmérsékletfüggő spinátmenetet mutattunk ki. Az $\alpha-F e-f t a l o c i a n i n$ rácsába történő nagy mennyiségü oxigén bevitele esetén, hosszú $\mu$-peroxo hidas $-\mathrm{Fe}-\mathrm{O}-\mathrm{O}-\mathrm{Fe}-$ láncok képződésére következtettünk a ${ }^{57} \mathrm{Fe}$ Mössbauer-spektroszkópiai méréseink alapján. A külső mágneses térben és alacsony hőmérsékleteken végzett Mössbauer- és mágneses mérések antiferromágneses csatolás jelenlétét mutatták ki vizes szuszpenzióban nagymértékben oxigénben kezelt $\alpha-\mathrm{Fe}$-ftalocianinban. Az antiferromágneses csatolást a hosszú $\mu$-peroxo - Fe-O-O-Fe- láncok közötti szuperkicserélődéssel közvetített kicserélődési kölcsönhatással magyaráztuk.

A külső mágneses térben és alacsony hőmérsékleteken végzett ${ }^{57} \mathrm{Fe}$ Mössbauer-mérések rendkívül nagy, $\mathrm{B} \approx 156$ $\mathrm{T}$ és $\mathrm{B} \approx 92 \mathrm{~T}$ hiperfinom mágneses tereket mutattak az alacsony koordinációjú, egy vas-centrumú $\mathrm{Fe}\left[\mathrm{C}\left(\mathrm{SiMe}_{3}\right)_{3}\right]_{2}$ és $\mathrm{Fe}\left[\mathrm{N}\left(\mathrm{SiPh}_{2} \mathrm{Me}\right)_{2}\right]_{2}$ molekula mágnesekben. Ez nyilvánvalóan mutatja a nem-befagyott pályamomentum jelenlétét, aminek köszönhetően a vas(II) ion jelentősen megváltozott mágneses momentummal vesz részt a vegyület mágneses tulajdonságainak kialakításában. Két atom koordinált vas-amido-komplexekben korrelációt állapítottunk meg a $\mathrm{N}-\mathrm{Fe}-\mathrm{N}$ kötésszög és a $\boldsymbol{B}_{\mathrm{hf}}$ hiperfinom tér között, ami azt mutatta, hogy a N-Fe-N kötésszög $180^{\circ}$-tól való eltérésének a növekedése a befagyott pályamomentum-, és ennek a hiperfinom térhez való járulékának a csökkenéséhez vezet. Eredményeink arra utalnak, hogy kicserélődési kölcsönhatás van jelen a vizsgált alacsony koordinációjú vas-komplex molekuláris mágnesek molekuláris egységei között.

\section{Köszönetnyilvánítás}

Hálás köszönetünket fejezzük ki Dr. Várhelyi Csabának (Babes Bólyai Egyetem, Kolozsvár) a glioxim komplexek készítéséért és diszkussziókban való részvételért, Prof. Libor Machala-nak és Dr. Jiri Pechousek-nek (Palacky Egyetem, Olomouc, a külső térben végzett alacsonyhőmérsékleti Mössbauer- és mágneses mérésekért, Lengyel Attilának (Wigner Intézet) egyes glioxim Mössbauerspektrumok méréséért, Prof. Amar Nath-nak (North Carolina Egyetem, Asheville) oxigénben kezelt vas-ftalocianin mintákért és diszkussziókban való részvételért, Prof. Szepes Lászlónak (ELTE) a diszkussziókban való részvé- 
telért, valamint NKFIH támogatásért (OTKA projekt No K43687, K68135, K111692, K129210, K115913, K115784) és (No TÉT_16-1-2016-0002).

\section{Hivatkozások}

1. O. Kahn, Molecular Magnetism, VCH Publishers, New York, 1993. ISBN 1-56081-566-3

2. K. Itoh, M. Kinoshita Molecular Magnetism, Kodansha and Gordon \& Breach: Tokyo and Amsterdam, 2001. ISBN 4-06-209070-1

3. R. Sessoli, D. Gatteschi, A. Caneschi, MA. Novak, Nature (London) 1993, 365:141-143. https://doi.org/10.1038/365141a0

4. E. Coronado, Nature Reviews Materials, 2019, https://doi.org/10.1038/ s41578-019-0146-8

5. L. Bogani, W. Wersdorfer, Nature Materials, 2008, 7, 179186 , https://doi.org/10.1038/nmat2133

6. I. Dézsi, B. Molnár, T. Tarnóczi, K. Tompa, J Inorg Nucl Chem 1967,29, 2486. https://doi.org/10.1016/0022-1902(67)80307-5

7. P. Gütlich, Spin crossover in iron(II)-complexes. In: Metal Complexes. Structure and Bonding, vol 44. Springer, Berlin, Heidelberg, 1981, doi.org/10.1007/BFb0111269

8. D. Gatteschi, R. Sessoli, J. Villain, Molecular Nanomagnets, Oxford University Press, 2006. ISBN-13: 9780198567530 https://doi.org/10.1093/acprof:oso/9780198567530.001.0001

9. R. Sessoli, H L Tsai, A.R. Shake, S. Wang, J.B. Vincent, K. Folting, D. Gatteschi, G. Christou, D.M. Hendrickson, J. Am. Chem. Soc. 1993, 115, 1804, https://doi.org/10.1021/ja00058a027

10. R. Sessoli, D. Gatteschi, A. Caneschi, M. Novak, Nature, 1993,365,141, https://doi.org/10.1038/365141a0

11. E. del Barco, A. D. Kent, S. Hill, J. M. North, N. S. Dalal, E. M. Rumberger, D. N. Hendrickson, N. Chakov, G. Christou, J Low Temp Phys, 2005, 140, 119, https://doi.org/10.1007/s10909-005-6016-3

12. M.N. Luenberger, D. Loss, Nature, 2001, 401, 789, https://doi.org/10.1038/35071024

13. L. Cianchi, F. Del Giallo, M. Lantieri, P. Moretti, G. Spina, and A. Caneschi, Phys. Rev. 2004, B 69, 014418, https://doi.org/10.1103/PhysRevB.69.014418

14. L. Cianchi, F. Del Giallo, M. Lantieri, Hyperfine Interact 2006,168, 1115. https://doi.org/10.1007/s10751-006-9411-5

15. J. M. Zadrozny, D.J. Xiao, M. Atanasov, G. J. Long, F. Grandjean, F. Neese, J. R. Long, Nature Chem. 2011, 5, 2013, https://doi.org/10.1038/nchem.1630

16. G. Abbas, Y. Lan, V. Mereacre,W. Wernsdorfer, R. Clerac, G. Buth, M.T. Sougrati, F.Grandjean, G.J. Long, C.E. Anson,, A. K. Powell, Inorg. Chem., 2009, 48, 9345-9355, https://doi.org/10.1021/ic901248r

17. E. Molins, M. Gich, J. Tejada, J. M. Grenèche and F. Macià, EPL, 2014, 108, 47004, https://doi.org/10.1209/0295-5075/108/47004

18. E. Kuzmann, Z. Homonnay, S, Nagy, K. Nomura, Mössbauer Spectroscopy, In: Vértes, A; Nagy, S; Klencsár, Z; Lovas, R; Rösch, F (szerk.) Handbook of Nuclear Chemistry, New York, Heidelberg, Springer, 2011. https://doi.org/10.1007/978-1-4419-0720-2_25

19. P. Gütlich, B. Eckhard, A. X. Trautwein, Mössbauer Spectroscopy and Transition Metal Chemistry, Springer, New York, 2011. ISBN 978-3-54088427-8 https://doi.org/10.1007/978-3-540-88428-6
20. A. Vértes, K. Burger, L. Korecz, Mössbauer spectroscopy, Akadémiai K.-Elsevier, Budapest, Amsterdam, 1979. ISBN 0444997822

21. N.N. Greenwood, T.C. Gibb, Mössbauer spectroscopy, Chapman \& Hall, London, 1971. ISBN 978-94-009-5697-1

22. J. G. Stevens, V.E. Stevens, Mössbauer Effect Data Index (MERDI), Adam Hilger, London, 1966-79. ISSN: 0272-2755 https://doi.org/10.1007/978-1-4757-5903-7

23. U. Gonser, Mössbauer spectroscopy, Springer, New York, 1975. ISBN 978-3-662-30785-4

24. C. Várhelyi, Jr, A. Kovács, D. Nemcsok, Z. Németh, E. Kuzmann, A. Vértes, K Vékey, C. Várhelyi, G. Pokol, Journal of Coordination Chemistry, 2007, 60, 379-392, https://doi.org/10.1080/00958970600783969

25. Z. Németh, E. Kuzmann, A. Vértes, A. Kovács, Cs. Várhelyi Jr, Cs. Várhelyi, Hyperfine Interactions, 2008,185, 159-165, https://doi.org/10.1007/s10751-008-9832-4

26. E. Kuzmann, A. Lengyel, Z. Homonnay, Cs. Várhelyi, Jr, Z. Klencsár, S. Kubuki, R. Szalay, Hyperfine Interactions, 2014, 226, 181-185. https://doi.org/10.1007/s10751-013-0916-4

27. Cs, Várhelyi Jr., E, Kuzmann, Z. Homonnay, A. Lengyel, Gy. Pokol, V. Izvekov, R. Szalay, E. Kun, E. Tomoia-Cotisel, M. Covaci, V.K. Garg, A.C. Olivera, F. Goga, J. Radioanal. Nucl. Chem, 2015, 304, 745-750. https://doi.org/10.1007/s10967-014-3849-8

28. Cs, Várhelyi Jr, A. Lengyel, Z Homonnay, R. Szalay. Gy. Pokol. I M. Szilágyi, P, Huszthy, J. Papp, F, Goga. L, -M Golban, E. Kuzmann, Hyperfine Interactions, 2017, $238: 87$ https://doi.org/10.1007/s10751-017-1463-1

29. Cs, Várhelyi Jr., E, Kuzmann, Z. Homonnay, Gy. Pokol, I. Szilágyi, P. Huszthy, R. Szalay, J. Papp, F. Goga, L-M. Golban, Acta Scientiarum Transylvanica - Múzeumi Füzetek, 2017, 25, 87-94, http://hdl.handle.net/10598/30165

30. N. Kopelev, V. Chechersky, A. Nath, Y.L. Wang, E. Kuzmann, B. Zhang, G.H. Via, Chemistry of Materials 1995, 7, 1419-21, 0897-475619512807-1419\$09.00 https://doi.org/10.1021/cm00055a022

31. E. Annese, G. DiSanto, F. Choueikani, E. Otero, P. Ohresser, ACS Omega, 2019, 4, 5076-5082, https://doi.org/10.1021/acsomega.9b00214

32. E. Kuzmann, Z. Homonnay, A. Vértes, S. Li, H. Yin, S. Kubuki, Y. Wei, A. Nath, X. Chen, .J. Li, Journal of Solid State Chemistry, 2003, 170, 118-123, https://doi.org/10.1016/S0022-4596(02)00035-X

33. E. Kuzmann, A. Nath, V. Chechersky, S. Li, Y. Wei, X. Chen, J. Li, Z. Homonnay, M. Gál, V.K. Garg, Z. Klencsár, A. Vértes, Hyperfine Interactions, 2002, 139/140, 631-639 https://doi.org/10.1023/A:1021291316033

34. H. Yin, S. Kubuki, Z. Homonnay, E. Kuzmann, A. Vértes, Y. Wei, A Nath, Open Inorganic Chemistry Journal, 2008,2, 69-72. https://doi.org/10.2174/1874098700802010069

35. E. Kuzmann, Z. Homonnay, A. Mylonakis, H. Yin, Y Wei, K. Kovács, S. Kubuki, Z. Klencsár, A. Vértes, A. Nath, Journal of Physics Conf. Ser. 2010, 217, https://doi.org/10.1088/1742-6596/217/1/012029

36. E. Kuzmann, J. Pechousek, J. Cuda, H. Yin, Y. Wei, Z. Homonnay, Z. Klencsár, A. Horváth, L. Machala, S. Kubuki, G. Zopellaro, R. Zboril, A. Nath, AIP Conference Proceedings 2014,1622, 97-103, https://doi.org/10.1063/1.4898616

37. M. Holynska, Single Molecule Magnets, Wiley, Marburg, 2019. ISBN: 978-3-527-34321-8

38. W.M. Reiff, A.M. LaPointe, E.H. Witten, J. Am. Chem. Soc., 2004,126 10206 . https://doi.org/10.1021/ja030632w 
39. E. Kuzmann, R. Szalay, A. Vértes, Z. Homonnay, I. Pápai I, P. de Chatel, L. Szepes, Hyperfine Interact. 2008, 185, 185189. https://doi.org/10.1007/s10751-008-9826-2

40. E. Kuzmann, R. Szalay, A. Vértes, Z. Homonnay, I. Pápai, P. de Chatel, Z. Klencsár, L. Szepes, Structural Chemistry 2009, 20, 453-460. https://doi.org/10.1007/s11224-009-9440-1

41. W.M. Reiff, C.E. Schulz, M.-H. Whangbo, J.I. Seo, Y.S. Lee, G.R. Potratz, C.W. Spicer, G.S. Girolami, J. Am. Chem. Soc. 2009,131, 404. https://doi.org/10.1021/ja806660f

42. W. A. Merrill, T.A. Stich, M. Brynda, G. J. Yeagle, J. C. Fettinger, R.De Hont, W. M. Reiff, C. E. Schulz, R. D. Britt, and P. P. Power, J. Am. Chem. Soc. 2009, 131, 12693-12702, https://doi.org/10.1021/ja903439t

43. M. Atanasov, J. M. Zadrozny J. R. Long, F. Neese, Chem. Sci., 2013,4, 139 , https://doi.org/10.1039/C2SC21394J
44. J. M. Zadrozny, M. Atanasov, A.M. Bryan, C.-Y. Lin, B.D. Rekken, P.P. Power, F. Neese, J.R. Long Chem. Sci. 2013, 4, 125. https://doi.org/10.1039/C2SC20801F

45. J. M. Zadrozny, D.J. Xiao, M. Atanasov, G. J. Long, F. Grandjean, F. Neese, J. R. Long, Nature Chem. 2013, 5, 577 81 https://doi.org/10.1038/nchem. 1630

46. A. M. La Pointe, Inorg. Chim. Acta 2003, 345, 359-362. https://doi.org/10.1016/S0020-1693(02)01309-9

47. E. Kuzmann, G. Zoppellaro, J. Pechousek, J. Cuda, Z. Klencsár, Z. Homonnay, J. Tucek, R. Szalay, M. Pápai, L. Machala, R. Zboril, Eur. J. Inorg. Chem. 2014, 3178-3183, https://doi.org/10.1002/ejic.201402033

48. E. Kuzmann, G. Zoppellaro, J. Pechousek, Z. Klencsár, L. Machala, J. Tucek, Z. Homonnay, J. Cuda, R. Szalay, M. Pápai, Struct Chem., 2016, 28, 975-983,. https://doi.org/10.1007/s11224-016-0899-2

\section{Mössbauer study of molecular magnetism of some organometallic compounds}

Here we summarize our main results, obtained by Mössbauer spectroscopy, on the spin transitions found either for iron-bis-glioxime complexes [26] and for oxygenated iron phthalocyanines [35], and the results on the observation of low temperature magnetic exchange couplings found either in oxygenated iron phthalocyanines [36] or, together with extraordinary high hyperfine fields, in single molecule magnets $[47,48]$.

In our work we could advantageously use ${ }^{57} \mathrm{Fe}$ Mössbauer spectroscopy as a unique method for distinguishing low spin and high spin iron states, for detecting spin transitions and spin crossovers, for measuring hyperfine fields at the site of iron nucleus and determining the type of magnetic couplings in iron compounds.

Our earlier Mössbauer studies [26] performed with novel $\left[\mathrm{Fe}^{\mathrm{II}}(\mathrm{DioxH})_{2} \mathrm{~L}_{2}\right]$ iron-glyoxime complexes having short alkyl chains revealed always only low spin $\mathrm{Fe}^{\mathrm{II}}$ states being consistent with $\mathrm{Fe}-\mathrm{N}$ distances shorter than $0.2 \mathrm{~nm}$.

We have found high spin $\mathrm{Fe}^{\mathrm{II}}$ state when the short alkyl chains were substituted by high volume demand branched alkyl chains, resulting a significant increase in the $\mathrm{Fe}-\mathrm{N}$ bond distances becoming favorable for high spin $\mathrm{Fe}^{\mathrm{II}}$ state. Thus, ${ }^{57} \mathrm{Fe}$ Mössbauer spectroscopy proved that the spin state of iron can be manipulated from low spin state to high spin state by replacing the short alkyl chains with branched ones in iron-glioxime complexes.

We have performed oxygenation of $\alpha$-Fe- and $\beta$-Fe-phthalocyanines in dry and wet suspensions and characterized the oxygen adducts by the help of ${ }^{57} \mathrm{Fe}$ Mössbauer spectroscopy. In oxygenated $\beta-\mathrm{Fe}$-phthalocyanine we have found a temperature dependent low spin-high spin crossover of one of the oxygen adducts based on the temperature dependent changes observed in the Mösssbauer parameters of subspectra belonging to the oxygen adducts. In the case of the introduction of high amount of oxygen into the lattice of $\alpha$-Fe-phthalocyanine we have suggested the formation of long $\mu$-peroxo bridged $-\mathrm{Fe}-\mathrm{O}-\mathrm{O}-\mathrm{Fe}-$ chains, based on ${ }^{57} \mathrm{Fe}$ Mössbauer spectroscopic data. In-field low temperature Mössbauer and magnetic measurements revealed the occurrence of antiferromagnetic coupling in $\alpha$-Fe-phthalocyanine highly oxygenated in wet suspension. The exchange interaction is considered to be mediated via superexchange between the long $\mu$-peroxo bridged $-\mathrm{Fe}-\mathrm{O}-\mathrm{O}-\mathrm{Fe}-$ chains.

Organometallic compounds of single molecular magnets (SMMs) show stable magnetization of molecular origin via a large axial magnetic anisotropy. We have synthesized one of the presently known iron-bearing SMMs, the two coordinate $(\mathrm{C}-\mathrm{Fe}-\mathrm{C})$ linear molecule $\mathrm{Fe}\left[\mathrm{C}\left(\mathrm{SiMe}_{3}\right)_{3}\right]_{2}$, and investigated by ${ }^{57} \mathrm{Fe}$ Mössbauer spectroscopy.

We have found that the $\mathrm{Fe}\left[\mathrm{C}\left(\mathrm{SiMe}_{3}\right)_{3}\right]_{2}$ compound shows an extraordinary high hyperfine magnetic field $(\sim 157 \mathrm{~T})$ measured by ${ }^{57} \mathrm{Fe}$ Mössbauer spectroscopy at $20 \mathrm{~K}$. The origin of this huge hyperfine magnetic field is undoubtedly attributed to the unquenched orbital contribution to the atomic angular momentum of $\mathrm{Fe}^{\mathrm{II}}$, associated with the sterically fixed linear coordination geometry of the $\mathrm{Fe}^{\mathrm{II}}$. In order to elucidate the nature of magnetic coupling in the $\mathrm{Fe}\left[\mathrm{C}\left(\mathrm{SiMe}_{3}\right)_{3}\right]_{2} \mathrm{SMM}$ compound we performed Mössbauer measurements at low temperatures with and without external magnetic fields applied in parallel direction to the $\gamma$-rays. The in field ${ }^{57} \mathrm{Fe}$ Mössbauer and magnetization measurements revealed ferromagnetic coupling of magnetic moments in $\mathrm{Fe}\left[\mathrm{C}\left(\mathrm{SiMe}_{3}\right)_{3}\right]_{2}$ / ferrihydrite hetero-mixture at $\mathrm{T}=5 \mathrm{~K}$. These findings underline the sensitivity of SMM molecules to local alterations of their ligand-environment, which property may be considered as additional synthetic strategy to be used to tune the magnetic regime of these types of molecular systems.

Magnetic coupling between SMM units may exist in other related Fe compounds as well, such as in the analogous linear two-coordinated iron complexes where iron is coordinated with nitrogen atoms instead of carbon. Our low temperature in-field ${ }^{57} \mathrm{Fe}$ Mössbauer measurements of low coordinated monoiron centered 
molecular magnet $\mathrm{Fe}\left[\mathrm{C}\left(\mathrm{SiMe}_{3}\right)_{3}\right]_{2}$ exhibited also an extraordinary hyperfine field, as large as $\boldsymbol{B} \approx 92 \mathrm{~T}$. This also evidences the presence of an unquenched orbital angular moment, through which magnetism visualizes itself with a considerably altered iron magnetic moment. ${ }^{57} \mathrm{Fe}$ Mössbauer and magnetization measurements showed also the presence of considerable magnetic exchange interactions in $\mathrm{Fe}\left[\mathrm{N}\left(\mathrm{SiPh}_{2} \mathrm{Me}\right)_{2}\right]_{2}$. The ferromagnetic character based on the exchange interaction what we observed experimentally with both $\mathrm{Fe}\left[\mathrm{C}\left(\mathrm{SiMe}_{3}\right)_{3}\right]_{2}$ and $\mathrm{Fe}\left[\mathrm{N}\left(\mathrm{SiPh}_{2} \mathrm{Me}\right)_{2}\right]_{2} \mathrm{SMM}$ compounds, which complexes contain only one $\mathrm{Fe}$ atom within the molecule, cannot be understood in the frame of conventional model of the direct exchange interaction between the irons, because the closest iron neighbors (located in separate molecules) are too far from each other (at a distance around $0.8 \mathrm{~nm}$ ) to produce ferromagnetic coupling. The indirect exchange via the nonmagnetic atoms, like carbon, nitrogen or silicon, is also not supported enough by the theoretical calculations since no satisfactorily considerable spin densities were indicated by the DFT calculations on atoms other than iron in these molecules. Our cases are thus different from those MMS molecules in which multiatomic clusters are present where the intramolecular exchange interactions among spinbearing centres are well understood.

For two-coordinated iron amides a correlation between the N-Fe-N angle and $\boldsymbol{B}_{\mathrm{hf}}$ established revealing that increasing deviation of the $\mathrm{N}-\mathrm{Fe}-\mathrm{N}$ angle from $180^{\circ}$ leads to a decreasing quenching of the orbital moment and its contribution to the hyperfine magnetic field.

Our results refer to the presence of appreciable magnetic exchange interactions between molecular units of the investigated molecule magnets of low coordinate iron complexes. 